\title{
Evaluation of Self-Development Ability and Study of Its Obstacle Factors for State-Owned Forest Farms: Applying the SEM-PPM
}

\author{
Jiangdi Bai ${ }^{D}$, Pan Tan, Wenhui Chen * and Junchang Liu \\ School of Economics and Management, Beijing Forestry University, Beijing 100083, China; \\ baijiangdi16@163.com (J.B.); binglianxueer01@163.com (P.T.); liujunchang@vip.sina.com (J.L.) \\ * Correspondence: wenhui@bjfu.edu.cn
}

check for updates

Citation: Bai, J.; Tan, P.; Chen, W.;

Liu, J. Evaluation of Self-Development Ability and Study of Its Obstacle Factors for State-Owned Forest Farms: Applying the SEM-PPM. Sustainability 2021, 13, 3119. https://doi.org/ $10.3390 /$ su13063119

Academic Editor: C. Ronald Carroll

Received: 23 January 2021

Accepted: 8 March 2021

Published: 12 March 2021

Publisher's Note: MDPI stays neutral with regard to jurisdictional claims in published maps and institutional affiliations.

Copyright: (c) 2021 by the authors. Licensee MDPI, Basel, Switzerland. This article is an open access article distributed under the terms and conditions of the Creative Commons Attribution (CC BY) license (https:// creativecommons.org/licenses/by/ $4.0 /)$.

\begin{abstract}
State-owned forest farms (SOFFs) help maintain forest ecological security and hold an important strategic position in China's development. In this study we used 1305 sample data from 16 provinces, a structural equation model (SEM), and a projection pursuit model (PPM) to evaluate the self-development abilities of SOFFs, and used the obstacle model to analyze factors hindering these abilities in various provinces, at different development levels, and with different subordination relationships. The results show that (1) the self-development abilities of SOFFs remain weak, and there are many more provinces with low than with high levels; (2) the subordination relationship significantly affects the self-development ability, which is the highest for municipal SOFFs; and (3) social services, people's livelihood security, management ability, and forest resources are the main constraints for SOFF's self-development abilities, and people's livelihood security has the greatest influence for SOFFs with high self-development abilities, while social services are the most important for those with low self-development abilities.
\end{abstract}

Keywords: state-owned forest farms; self-development ability; obstacle factors; structural equation modeling; projection pursuit model

\section{Introduction}

State-owned forest farms (SOFFs) help maintain forest ecological security and hold an important strategic position in China's development. They were established when the new China was founded, experiencing rapid development in the 1960s, slight regression in the 1970s, a stable recovery in the 1980s, stable development in the 1990s, and fluctuating development in the 2000s amid a resource and economic crisis, revitalizing development in the current stage. In 2013, there were 3485 SOFFs designated as poor forest farms, accounting for $72 \%$ of the total. The public nature of SOFFs means they largely rely on government support for their development, but the cultivation and improvement of their self-development is easily ignored, which can stall their overall development. To address this, the Chinese government began to provide financial and policy support for impoverished SOFFs in 1998, including the Measures for the Administration of Poverty Alleviation Funds of the Poverty State-Owned Forest Farms in 1998, the Indicators and Defining Method of the Poverty State-Owned Forest Farms (LY/T 2088-2013) in 2013, and the State-Owned Forest Farms Reform Program issued by the central committee of the Communist Party of China and the State Council in 2015 (launched nationwide and incorporated into the national strategy). To date, poverty alleviation work for SOFFs has been carried out for 20 years, and achieved substantial results, such as a marked increase in the standards of production and living, a doubling of workers' wages and incomes, and financial security for workers through social insurance. According to the three development stages—survival, self-esteem, and freedom-after basic survival is guaranteed, the SOFF considers how to improve its self-development to achieve revitalization and development, and then moves to the self-esteem stage. It is important to evaluate the capacity for self-development and identify any obstacles in a comprehensive and scientific fashion, so as to promote the future development of SOFFs. 
Academic research on the ability for organizational self-development has mainly included public institutions, cooperatives, science and technology parks, and industrial management and enterprises, but rarely involved SOFFs. The research has mainly revolved around the concept, composition, evaluation methods, and influencing factors for the said ability, as shown in Table 1. It finds that (1) the concept changes with the object, but its core content remains the same [1]; (2) The composition, like the concept, changes with the object [1-10]; (3) The evaluation method includes objective and subjective valuation methods, but they tend to be used separately rather than in combination, which has both advantages and disadvantages in terms of retaining subjective and objective information [4-7,9-11]; (4) In the influencing factors, the influence of managerial ability mainly comprises three aspects [12]. First, it influences the development prospects of enterprises, that is, their development directions, by influencing the effects of management on decision-making [13]. Second, it affects the strategic adjustment of enterprises by affecting the quality of internal control, that is, the quality of development [14]. Third, it promotes the positive relationship between the internal control and sustainable development of enterprises [15]. The higher the internal control quality, the stronger the ability of the enterprise for sustainable development $[15,16]$. At the same time, the internal control quality is affected by the characteristics and reputation of management [17]. Xia and Hou found that the fulfillment of enterprise social responsibility (CSR) could promote the sustainable development of enterprises, and CSR played an intermediary role in the process when internal control affected the ability of enterprises for sustainable development [16].

Table 1. Research on the ability for organizational self-development.

\begin{tabular}{|c|c|c|}
\hline Type & & Details \\
\hline The concept & The developm & it ability derived internally [1] \\
\hline \multirow{12}{*}{ The composition } & Public libraries & $\begin{array}{l}\text { The abilities for innovative development, main factor aggregation, } \\
\text { resource utilization, coordinated development, and public } \\
\text { influence [1] }\end{array}$ \\
\hline & Farmers' cooperatives & $\begin{array}{l}\text { Chairman ability and abilities for financing, technical innovation, } \\
\text { and marketing [2] }\end{array}$ \\
\hline & Tobacco and farmer cooperatives & $\begin{array}{c}\text { The dependence on the tobacco sector, profitability, and member } \\
\text { benefits [3] }\end{array}$ \\
\hline & Modern agricultural demonstration parks & $\begin{array}{l}\text { The scientific and technological support ability, demonstration } \\
\text { driving ability, hardware investment, economic development } \\
\text { ability, and sustainable development ability [4] }\end{array}$ \\
\hline & New energy industries & $\begin{array}{l}\text { The resource endowment, institutional environment, technical talents, } \\
\text { market development, and economic costs [5] }\end{array}$ \\
\hline & Cultural industries & The productivity, driving forces, and influences [6] \\
\hline & Big data industries & $\begin{array}{l}\text { The basic development ability, industrial development support ability, } \\
\text { system coordination and integration ability, overall level of } \\
\text { informatization and information industry, information infrastructure } \\
\text { support ability, science and technology, and talents [7] }\end{array}$ \\
\hline & "Internet + agriculture" & Society, the economy, resources, and the environment [8] \\
\hline & $\begin{array}{c}\text { "Internet + agricultural products and its processed } \\
\text { products industry" }\end{array}$ & The degrees of development, continuity, and coordination [8] \\
\hline & $\begin{array}{c}\text { "Internet + agricultural products and its processed } \\
\text { products services" }\end{array}$ & $\begin{array}{c}\text { The indices of overall strength, internal structure, and } \\
\text { development matching [8] }\end{array}$ \\
\hline & Small and micro-enterprises & $\begin{array}{l}\text { The leadership ability, innovation income, financing ability, } \\
\text { enterprise culture, and product development [9] }\end{array}$ \\
\hline & The state-owned enterprise of Xinjiang corps & $\begin{array}{l}\text { The capability for resource utilization, operation and management, } \\
\text { profitability, and innovation [10] }\end{array}$ \\
\hline The evaluation method & \multicolumn{2}{|c|}{$\begin{array}{l}\text { Weighted averages [9], principal component analysis [10], the combined multivariate statistical method of global principal } \\
\text { component analysis [6], the analytic hierarchy process [5], the fuzzy analytic hierarchy process [4], the DEMATEL and system } \\
\text { simulation method [11], and the BP neural network evaluation model based on entropy weights [7] }\end{array}$} \\
\hline The influencing factors & \multicolumn{2}{|c|}{ Enterprise factors and management ability [12] } \\
\hline
\end{tabular}

Research on SOFF development has been carried out from different perspectives. Luo et al. comprehensively evaluated the benefits in five dimensions: the ecological benefits, improvement of people's livelihoods, social benefits, economic benefits, and 
development ability [18]. Xie and Hu constructed a classification index system from five indicators: the management level, resource level, operating conditions, ecological and non-forest industry development level, and local economic benefits [19]. Miao and Ye built a sustainable management index system for subtropical areas based on forest management, human resources, and social resources, combining field investigations and drawing on the standards and indicators for the sustainable management of forests at the international, national, regional, and management levels [20]. Wang and Chen constructed an evaluation index system at the county development level based on five aspects: infrastructure conditions, self-development potential, forest resources, social contribution, and economic development level [21]. Xu and Wang constructed an evaluation index system of social performance based on five aspects: resource environment benefit, living standard benefit, economic development benefit, cultural soft power benefit and democracy benefit [22].

Many types of organizational subjects have been involved in research on organizational self-development ability, but the research has mainly focused on private institutions, with less attention directed towards public welfare institutions (such as SOFFs). Research on the development of SOFFs has mostly been based on a macro rather than micro view. Based on the above analysis, this study constructed a system to evaluate the self-development ability of SOFFs, and then evaluated it with a structural equation model (SEM) and projection pursuit model (PPM), analyzing the obstacles to development in various provinces, the different levels of development, and subordination relationships using an obstacle degree model with 1305 sample forest farm data from 16 provinces.

\section{Index System Construction}

The essence of self-development ability is realizing the optimal allocation of resources by relying on one's own strength [23]. The development of a specific forest farm is faced with a scarcity of resources, which necessitates the optimal allocation of the latter. This allocative efficiency determines the development of the SOFF, because the improvement of its production and life and the welfare of the employees all depend on the resources. Its development must be consistent with the ecological function orientation (the protection and cultivation of forest resources) and the development goals of public institutions (the provision of public services). Using the theory of the optimal allocation of resources and development requirements of SOFFs, in this study we analyzed the self-development ability of SOFFs in three aspects: the abilities for factor gathering, resource utilization, and public service. Factor gathering ability means the ability to attract and condense factors of production - in this case, the ability to use and produce economic value. The resource utilization ability is the ability to reasonably allocate the production factors created by SOFFs or gathered in the forest farms and convert them into economic value, which manifests as the use efficiency and output level of the factors. The public service ability is the ability to provide services to meet social demands, which mainly manifests as the guaranteeing of people's livelihoods and ecological supplies. These three are the comprehensive abilities that the behavioral subjects of SOFFs show in production and management activities, and they interact with one another. The factor gathering ability is critical for the development of a SOFF, the resource utilization ability determines how well the accumulated resources are used [24], and public service ability is the result of the development of the SOFF. An improved public service ability helps to garner attention from the government and society, affecting the SOFF's accumulation and development of various resources, and then further improves the ability to use resources. An improved resource utilization ability feeds back to public service ability, forming a virtuous cycle.

Based on the characteristics of SOFFs and the theoretical analysis of self-development ability, we constructed a multi-level and multi-dimensional system to evaluate the selfdevelopment ability of SOFFs, as shown in Table 2. The dimensions and their subdimensions are composed as follows: (1) Factor gathering ability (A1) includes forest resources (B1), hardware construction (B2), and innovation ability (B3). (2) Resource utilization ability (A2) includes management ability (B4), and profitability (B5). (3) Public service ability (A3) includes people's livelihood security (B6) and social services (B7). 
Table 2. System for evaluating self-development ability of State-owned forest farms (SOFFs).

\begin{tabular}{|c|c|c|c|}
\hline Dimension & Sub-Dimensions & Index & Index Explanation \\
\hline \multirow{10}{*}{$\begin{array}{l}\text { Factor } \\
\text { gathering } \\
\text { ability (A1) }\end{array}$} & \multirow{3}{*}{$\begin{array}{l}\text { Forest } \\
\text { resources (B1) }\end{array}$} & Unit stock volume (C1) [18-22] & $\begin{array}{l}\text { Forest stock per unit area }\left(\mathrm{m}^{3} / \mathrm{ha}\right) \text {. The higher the index, } \\
\text { the better the quality of the forest. }\end{array}$ \\
\hline & & Forest coverage rate $(\mathrm{C} 2)[18-22]$ & $\begin{array}{l}\text { Forest area as proportion of total operating area (\%). The } \\
\text { higher the index, the more forests there are. }\end{array}$ \\
\hline & & Non-public welfare forest area proportion (C3) $[18,19]$ & $\begin{array}{l}\text { Non-national or non-local public welfare forest as } \\
\text { proportion of total operating area (\%). The higher the } \\
\text { index, the greater the available range of forest resources. }\end{array}$ \\
\hline & \multirow{5}{*}{$\begin{array}{l}\text { Hardware } \\
\text { construction (B2) }\end{array}$} & Production and office housing (C4) $[18,19]$ & $\begin{array}{l}\text { Proportion of area in the production office accords with } \\
\text { the national construction standard (\%). The higher the } \\
\text { index, the better the operating conditions. }\end{array}$ \\
\hline & & Network coverage (C5) $[18,21]$ & $\begin{array}{c}\text { Access to the Internet (The value is } 0 \text { or } 1.0 \text { means No; } 1 \\
\text { means Yes). The index is } 1 \text {, the better the operating } \\
\text { conditions are. }\end{array}$ \\
\hline & & Traffic accessibility (C6) [18-20] & $\begin{array}{l}\text { Constructed length of highway and grade of highway in } \\
\text { forest per unit area }(\mathrm{km} / \mathrm{ha}) \text {. The higher the index, the } \\
\text { better the operating conditions. }\end{array}$ \\
\hline & & Forest road density $(\mathrm{C} 7)[21]$ & $\begin{array}{l}\text { Forest road length as proportion of total operating area } \\
(\mathrm{km} / \mathrm{ha}) \text {. The higher the index, the better the operating } \\
\text { conditions. }\end{array}$ \\
\hline & & Transportation facilities (C8) [19] & $\begin{array}{l}\text { Whether equipped with forest traffic facilities, such as } \\
\text { patrol cars and fire trucks (The value is } 0 \text { or } 1.0 \text { means } \\
\text { No; } 1 \text { means Yes). The index is } 1 \text {, the better the operating } \\
\text { conditions are. }\end{array}$ \\
\hline & \multirow{2}{*}{$\begin{array}{l}\text { Innovation } \\
\text { ability (B3) }\end{array}$} & $\begin{array}{l}\text { Proportion of senior high school (including technical } \\
\text { secondary school) and above graduates (C9) }[19,20]\end{array}$ & $\begin{array}{c}\text { Senior high school (including technical secondary } \\
\text { school) and above graduates as proportion of on-the-job } \\
\text { workers (\%). The higher the index, the higher the level } \\
\text { of cultural quality of workers. }\end{array}$ \\
\hline & & $\begin{array}{c}\text { Proportion of senior, intermediate professional, and } \\
\text { technical personnel (C10) [20] }\end{array}$ & $\begin{array}{c}\text { Senior, intermediate professional, and technical } \\
\text { personnel as proportion of on-the-job workers (\%). The } \\
\text { higher the index, the higher the skill level. }\end{array}$ \\
\hline \multirow{5}{*}{$\begin{array}{l}\text { Resource } \\
\text { utilization } \\
\text { ability (A2) }\end{array}$} & \multirow{2}{*}{$\begin{array}{l}\text { Management } \\
\text { ability (B4) }\end{array}$} & Per capita operating income (C11) $[19,21,22]$ & $\begin{array}{l}\text { Average annual operating income per person (yuan per } \\
\text { person per year). The higher the index, the higher the } \\
\text { level of operation. }\end{array}$ \\
\hline & & Proportion of asset expenditure of forest farms (C12) [18] & $\begin{array}{l}\text { Proportion of expenditure for infrastructure construction } \\
\text { and forest production expenditure in total income (\%). The } \\
\text { higher the index, the higher the level of operation. }\end{array}$ \\
\hline & \multirow{3}{*}{ Profitability (B5) } & Operating income proportion $(\mathrm{C} 13)[19,20]$ & $\begin{array}{l}\text { Operating income as proportion of total income (\%). The } \\
\text { higher the index, the higher the level of economic } \\
\text { development. }\end{array}$ \\
\hline & & Profit levels (C14) $[19,21]$ & $\begin{array}{l}\text { Total net profit (ten thousand yuan). The higher the } \\
\text { index, the higher the level of economic development. }\end{array}$ \\
\hline & & Asset-liability ratio (C15) [18-22] & $\begin{array}{l}\text { Total liabilities as proportion of total assets }(\%) \text {. This index } \\
\text { is a moderate index. In a certain range, the higher the } \\
\text { index is, the stronger the development ability will be. If the } \\
\text { index exceeds this range, it will be the opposite. }\end{array}$ \\
\hline \multirow{6}{*}{$\begin{array}{l}\text { Public service } \\
\text { ability (A3) }\end{array}$} & \multirow{3}{*}{$\begin{array}{l}\text { People's } \\
\text { livelihood } \\
\text { security (B6) }\end{array}$} & Employee income ratio (C16) [22] & $\begin{array}{l}\text { Average annual income of forest farm workers as } \\
\text { proportion of that of staff members in public institutions } \\
(\%) \text {. The higher the index, the higher the } \\
\text { self-actualization value of workers. }\end{array}$ \\
\hline & & Social security (C17) [19-22] & $\begin{array}{l}\text { Circumstances in which forest farm worker attends "five } \\
\text { insurances and housing fund" (The value is } 0 \text { or } 1.0 \\
\text { means No; } 1 \text { means Yes). The index is } 1 \text {, the more } \\
\text { employees feel safe and stable. }\end{array}$ \\
\hline & & Worker housing (C18) [21] & $\begin{array}{l}\text { Proportion of worker housing that accords with national } \\
\text { construction standards for worker housing (\%). The higher } \\
\text { the index, the higher the living standard of the workers. }\end{array}$ \\
\hline & \multirow{3}{*}{$\begin{array}{c}\text { Social } \\
\text { services (B7) }\end{array}$} & Construction of forest parks at all levels (C19) [21] & $\begin{array}{l}\text { Whether there are national or provincial forest parks } \\
\text { (The value is } 0 \text { or } 1.0 \text { means No; } 1 \text { means Yes). The } \\
\text { index is } 1 \text {, the higher the contribution to society. }\end{array}$ \\
\hline & & $\begin{array}{c}\text { Construction of various educational and cultural } \\
\text { bases (C20) }[21,22]\end{array}$ & $\begin{array}{l}\text { Whether there are educational bases or cultural sites } \\
\text { (The value is } 0 \text { or } 1.0 \text { means No; } 1 \text { means Yes). The } \\
\text { index is } 1 \text {, the more conducive it is to the propaganda } \\
\text { and education of forest culture, the higher its } \\
\text { contribution to society. }\end{array}$ \\
\hline & & Construction of scenic spots or geoparks (C21) [21] & $\begin{array}{c}\text { Whether located in a scenic area or built geopark (The } \\
\text { value is } 0 \text { or } 1.0 \text { means No; } 1 \text { means Yes). The index is } 1 \text {, } \\
\text { the higher the contribution to society. }\end{array}$ \\
\hline
\end{tabular}




\section{Methodology and Data}

The preliminarily constructed evaluation index system was only a framework obtained by a qualitative method, which is subjective to some extent [25]. Both objective (such as the entropy weight, gray correlation, and principal component analysis methods) and subjective (such as the analytic hierarchy process and fuzzy comprehensive evaluation method) weighting methods currently exist. In the former, the weight is determined according to the data characteristics of indicators or the data relationships existing among indicators (such as correlations); in the latter, the weight is determined according to the subjective judgment of expert experience. However, both methods ignore the interactions among the dimensions composed of indicators. These can be considered for evaluation using SEM [25]. Moreover, the relationships between the sub-dimensions and total dimensions are not simple and linear but non-linear, and they can be solved through PPM [26]. The specific steps are as follows.

\subsection{Standardized Treatment}

Before statistical measurement, the original index should be standardized to eliminate the impact of different dimensions. In this system, there are both moderate and positive indices; the asset-liability ratio is a moderate index, and the rest are all positive indices. The processing formula is as follows:

$$
x_{i j}=\left\{\begin{array}{l}
\frac{x_{i j}^{*}-\min x_{j}}{\max x_{j}-\min x_{j}}, \text { Positive index } \\
\frac{\left|x_{i j}^{*}-m_{j}\right|}{\max x_{j}-\min x_{j}}, \text { Moderate index }
\end{array} \quad i=1, \cdots, n ; j=1, \cdots, p\right.
$$

In Equation (1), $x_{i j}^{*}$ is the $j$-th evaluation index value of the $i$-th sample; $n$ and $p$ are, respectively, the number of samples and the number of evaluation indices; $\max x_{j}$ and $\min x_{j}$ are, respectively, the maximum and minimum values of the $j$-th evaluation index in the sample set; and $m_{j}$ are the moderate values of the $j$-th evaluation index. This equation is widely used in principal component analysis, the big data integration technology.

In this study we found that there is an inverted U-shaped relationship between profitability and the asset-liability ratio, and $\mathrm{Xu}$ et al. found that this relationship existed when profitability was below the median, with an inflection point of $61-65 \%$, and a U-shaped relationship existed when profitability was above the median, with an inflection point of $60 \%$ [27]. In light of the current development situation, the inverted U-shaped relationship is more representative for SOFFs. An asset-liability ratio of $50 \%$ for an enterprise is considered appropriate [28], and a SOFF with a ratio higher than $40 \%$ is defined as a poor forest farm [29]. Considering that the development levels of SOFFs are generally lower than those of enterprises in the market economy, $40 \%$ is considered a moderate value for the asset-liability ratio.

\subsection{Determination of Index Weight: SEM}

Considering that most of the data are not normally distributed, this study adopted the partial least squares (PLS) structural equation model. The model's variables include measurement and latent variables, and the model includes a measurement model and structural model. In the evaluation system, 21 indicators are measurement variables, and seven sub-dimensions are latent variables. The observation indicators of B3 and B7 are reflective construct indicators, which means that they have internal consistency and correlation. The rest of the observation indicators are formative constructs; that is, the correlation between them is low and they cannot replace one another. A change in one observation variable may not affect another. Therefore, the measurement model adopts a mixed model, in which a reflective indicator model is required to satisfy the reliability, convergence validity, and discriminate validity of the indicators, and a formative indicator model is required to satisfy the validity, construct validity, and discriminate validity of the indicators. The model is repeatedly modified by model fitting and quantitative testing to 
obtain the loading coefficient $\lambda$ between the index (observable variable) and the dimension (latent variable), which is the index's significance to the dimension to which it belongs. This equation has been used in the evaluation of forestry ecological security [25]. The weight coefficient of this index is calculated accordingly:

$$
\omega_{k j}=\lambda_{k j} / \sum_{j=1}^{p} \lambda_{k j}
$$

In Equation (2), $\omega_{k j}$ is the weight coefficient of the $j$-th index of the $k$-th sub-dimension. The score of each sub-dimension $B_{i k}$ is as follows:

$$
B_{i k}=\sum_{j} \omega_{k j} x_{i j}
$$

\subsection{Comprehensive Evaluation: PPM}

The PPM observes data from different angles to find the projection direction that best reflects the data's characteristics and exploits the information from it. It can realize the projection of high-dimensional data to a low-dimensional subspace when the weight coefficient is unknown. This equation has been used in the evaluation of sustainable development ability of enterprises [30].

The specific steps are as follows:

(1) Construct the projection indicator function.

Projected eigenvalue:

$$
z_{i}=\sum_{k=1}^{7} \alpha_{k} * B_{i k}
$$

Projection index function:

$$
Q(\alpha)=S_{z} * D_{z}
$$

Among them:

$$
\begin{aligned}
& S_{z}=\sqrt{\frac{\sum_{i}^{n}\left(z_{i}-\bar{z}\right)^{2}}{n-1}} \\
& D_{z}=\sum_{i=1}^{n} \sum_{j=1}^{n}\left(R-r_{i j}\right) * I\left(R-r_{i j}\right) \\
& r_{i j}=\left|z_{i}-z_{j}\right| \quad I\left(R-r_{i j}\right)=\left\{\begin{array}{l}
1, R \geq r_{i j} \\
0, R<r_{i j}
\end{array}\right.
\end{aligned}
$$

In Equation (4), $z_{i}$ is the projection value, and $a_{k}$ is the projection vector. 7 is the total number of sub-dimensions. In Equation (5), $Q(a)$ is the projection index function, $S_{z}$ is the standard deviation of the projected value $z_{i}$, and $D_{z}$ is the local density of the projected value $z_{i}$. In Equation (6), $R$ is the window radius of the local density, and its value should ensure that the number of projection points in the window is not too small and does not increase with an increase in projection points. Generally, its value is $0.1 * S_{z} . r_{i j}$ is the distance between samples, and $I\left(R-r_{i j}\right)$ is the unit jump function.

(2) Optimize the projection index function.

In a sample, the projection index function $Q(a)$ changes only with the projection direction. We need to maximize the projection index function to estimate the best projection direction for revealing some structural characteristics of high-dimensional data. The calculation formula is as follows:

$$
\begin{gathered}
\max Q(\alpha)=S_{z} D_{z} \\
\text { s.t. } \sum_{k=1}^{7} \alpha_{k}^{2}=1 \quad \alpha_{k} \geq 0
\end{gathered}
$$


The projection value $z_{i}$ of each sample can be obtained by substituting the obtained optimal projection direction value $\alpha^{*}$ into the projection eigenvalue formula. This result is the self-development ability score of the SOFF.

The solution of optimal projection direction requires the help of a real coding accelerating genetic algorithm (RAGA), which has been widely applied in optimizing projection index functions [30].

\subsection{Diagnostic Factors: Obstacle Degree Model}

Due to differences in the influence and contribution of each dimension for the selfdevelopment ability of a SOFF, this study adopted the obstacle degree model to further analyze the factors restricting the improvement of the self-development ability of SOFFs. This equation has been used in the obstacle degree diagnosis of land use performance. The obstacle degree formula for the $k$-th sub-dimension $Z_{k}$ is as follows:

$$
Z_{k}=\frac{\alpha_{k}^{*}\left(1-B_{i k}\right)}{\sum_{k=1}^{7} \alpha_{k}^{*}\left(1-B_{i k}\right)} * 100 \%
$$

\subsection{Data}

The data required for the research were mainly obtained from the national database for state-owned forest farms (2018), China statistical yearbook (2018), and forestry statistical yearbook (2018). After removing invalid samples, 1305 sample forest farms in 16 provinces were obtained, as shown in Table 3. The management area of SOFFS in southern collective forest area where the forestry development is mainly the collective forest management of farmers, is relatively small. Among them, the vast majority of SOFFS in Fujian are under municipal management that is relatively high level. The function of SOFFs in northeast state-owned forest area where the forestry development is dominated by state-owned forest management, is not divided between administrative unit and public institution. SOFFs in the central region that is mostly plain and mainly agricultural production, concentrated in the mountainous areas. The number of SOFFs in northwest little forest area where the population density is low, is not much but the management area is large.

Table 3. Distribution of sample forest farms in each province.

\begin{tabular}{|c|c|c|c|c|c|c|c|c|c|}
\hline Area & Province & $\underset{\left(\mathrm{km}^{2}\right)}{\text { Area }}$ & $\begin{array}{c}\text { Sample } \\
\text { Size }\end{array}$ & $\begin{array}{c}\text { Proportion } \\
(\%)\end{array}$ & Area & Province & Area $\left(\mathrm{km}^{2}\right)$ & $\begin{array}{c}\text { Sample } \\
\text { Size }\end{array}$ & $\begin{array}{c}\text { Proportion } \\
(\%)\end{array}$ \\
\hline \multirow{9}{*}{$\begin{array}{l}\text { Southern } \\
\text { collective } \\
\text { forest area }\end{array}$} & Zhejiang & 102,000 & 11 & 0.84 & northeast & Heilongjiang & 473,000 & 17 & 1.30 \\
\hline & Fujian & 121,300 & 82 & 6.28 & state-owned & Jilin & 187,400 & 336 & 25.75 \\
\hline & Jiangxi & 167,000 & 13 & 1.00 & forest area & Liaoning & 145,900 & 179 & 13.72 \\
\hline & Hubei & 185,900 & 221 & 16.93 & \multirow{3}{*}{ central area } & Henan & 167,000 & 24 & 1.84 \\
\hline & Hunan & 211,800 & 7 & 0.54 & & Shandong & 153,800 & 115 & 8.81 \\
\hline & Guangxi & 236,000 & 126 & 9.66 & & Shanxi & 156,300 & 11 & 0.84 \\
\hline & Guizhou & 176,000 & 105 & 8.05 & \multirow{2}{*}{$\begin{array}{l}\text { northwest little } \\
\text { forest area }\end{array}$} & Ningxia & 66,400 & 14 & 1.07 \\
\hline & Hainan & 34,000 & 23 & 1.76 & & Xinjiang & $1,660,000$ & 21 & 1.61 \\
\hline & & & & & Total & & $4,243,800$ & 1305 & 100 \\
\hline
\end{tabular}

\section{Results}

We used SmartPLS3 to run the SEM. After repeated correction, the indices C4, C6, and C18 were deleted. The modified operation results show the following: (1) The reflective indicator model can pass the reliability and validity tests; the Cronbach's alpha value for the internal consistency reliability test is 0.468 , denoting moderate reliability, and the composite reliability (CR) value for the synthetic reliability test is 0.704 , meeting standard requirements. The average variance extracted (AVE)value of the convergent validity is 0.461 , close to 0.5 , and the square root of the AVE value is larger than the coefficient of the correlation between latent variables, indicating discriminate validity. (2) In the formative indicator model, the index weight is significantly greater than 0.2 ; the collinear VIF value is less than 
10, showing indicator validity; and the AVE value between the latent variables is less than 0.7 , indicating discriminate validity. Finally, we worked out each index weight (Table 4) and each sub-dimension score through simple weighting. We then ran PPM using this score and MATLAB 2018, in which the parameters for the RAGA algorithm were set with reference to Su et al. (2018): the population size was 400 , the crossover probability was 0.8 , the mutation probability was 0.2 , the number of optimization variables was 7 , the random number required for the variation direction was 10, and the acceleration was 7 . Finally, the optimal projection direction for each sub-dimension was obtained, as shown in Table 4.

Table 4. Optimal sub-dimension projection direction and index weight of SOFFs.

\begin{tabular}{|c|c|c|c|c|}
\hline Dimension & Sub-Dimension & Sub-Dimensional Projection Direction & Index & Index Weight \\
\hline \multirow{8}{*}{ A1 } & \multirow{3}{*}{ B1 } & \multirow{3}{*}{0.265} & $\mathrm{C} 1$ & 0.190 \\
\hline & & & $\mathrm{C} 2$ & 0.357 \\
\hline & & & $\mathrm{C} 3$ & 0.453 \\
\hline & \multirow{3}{*}{ B2 } & \multirow{3}{*}{0.206} & C5 & 0.352 \\
\hline & & & $\mathrm{C} 7$ & 0.306 \\
\hline & & & $\mathrm{C} 8$ & 0.342 \\
\hline & \multirow{2}{*}{ B3 } & \multirow{2}{*}{0.024} & C9 & 0.691 \\
\hline & & & $\mathrm{C} 10$ & 0.309 \\
\hline \multirow{5}{*}{$\mathrm{A} 2$} & \multirow{2}{*}{ B4 } & \multirow{2}{*}{0.189} & $\mathrm{C} 11$ & 0.802 \\
\hline & & & $\mathrm{C} 12$ & 0.198 \\
\hline & \multirow{3}{*}{ B5 } & \multirow{3}{*}{0.019} & $\mathrm{C} 13$ & 0.549 \\
\hline & & & $\mathrm{C} 14$ & 0.225 \\
\hline & & & C15 & 0.226 \\
\hline \multirow{5}{*}{ A3 } & \multirow{2}{*}{ B6 } & \multirow{2}{*}{0.647} & $\mathrm{C} 16$ & 0.463 \\
\hline & & & $\mathrm{C} 17$ & 0.537 \\
\hline & \multirow{3}{*}{ B7 } & \multirow{3}{*}{0.658} & C19 & 0.573 \\
\hline & & & C20 & 0.249 \\
\hline & & & C21 & 0.179 \\
\hline
\end{tabular}

4.1. Comprehensive Evaluation of Self-Development Ability of SOFFs

4.1.1. Self-Development Ability of SOFFs for Each Province

We used natural breakpoint classification (Jenks) to classify the above results into three levels: low, general, and high. Finally, we visualized them on a map with ArcGis to analyze the spatial differentiation of the self-development ability of SOFFs in each province (Figure 1).

Fujian and Xinjiang (two provinces) are in the high-level area, and their projection values are 1.1431 and 1.0093, respectively. There are two main reasons for the high selfdevelopment ability in Fujian. First, the majority of SOFFs in Fujian are under municipal management, which makes it easier to obtain the management resources. Second, Fujian are located in areas of strong economic development in the south region, providing a certain economic basis for SOFFs. Those in Xinjiang are located in areas of weak economic development in the northwest region, but their forest land area accounts for $80 \%$ of the district, occupying an important ecological niche [31]. Therefore, SOFFs in Xinjiang have, for years, won long-term financial support from five key national forestry ecological projects: the Natural Forest Protection Project, Grain for Green Project, Natural Reserve Construction Project, "Three North" Shelter Forest Construction Project, and Central Ecological Benefit Compensation. This is also the main reason for Xinjiang's high capacity for self-development.

Guizhou, Shandong, Zhejiang, Shanxi, Hunan, and Hubei (six provinces) are in the general-level area, with projection values of $0.9507,0.9431,0.9199,0.8860,0.8610$, and 0.8280 , respectively. Only these provinces in China have successively issued relevant regulations and management measures for SOFFs, providing standardized and binding policies for 
their management. Compared with the Measures for the Management of State-owned Forest Farms issued by the National Forestry and Grassland Administration, these policies provide stronger guidance and operability for the management of SOFFs in their own provinces. To a certain extent, this has effectively improved the self-development ability of SOFFs in various provinces.

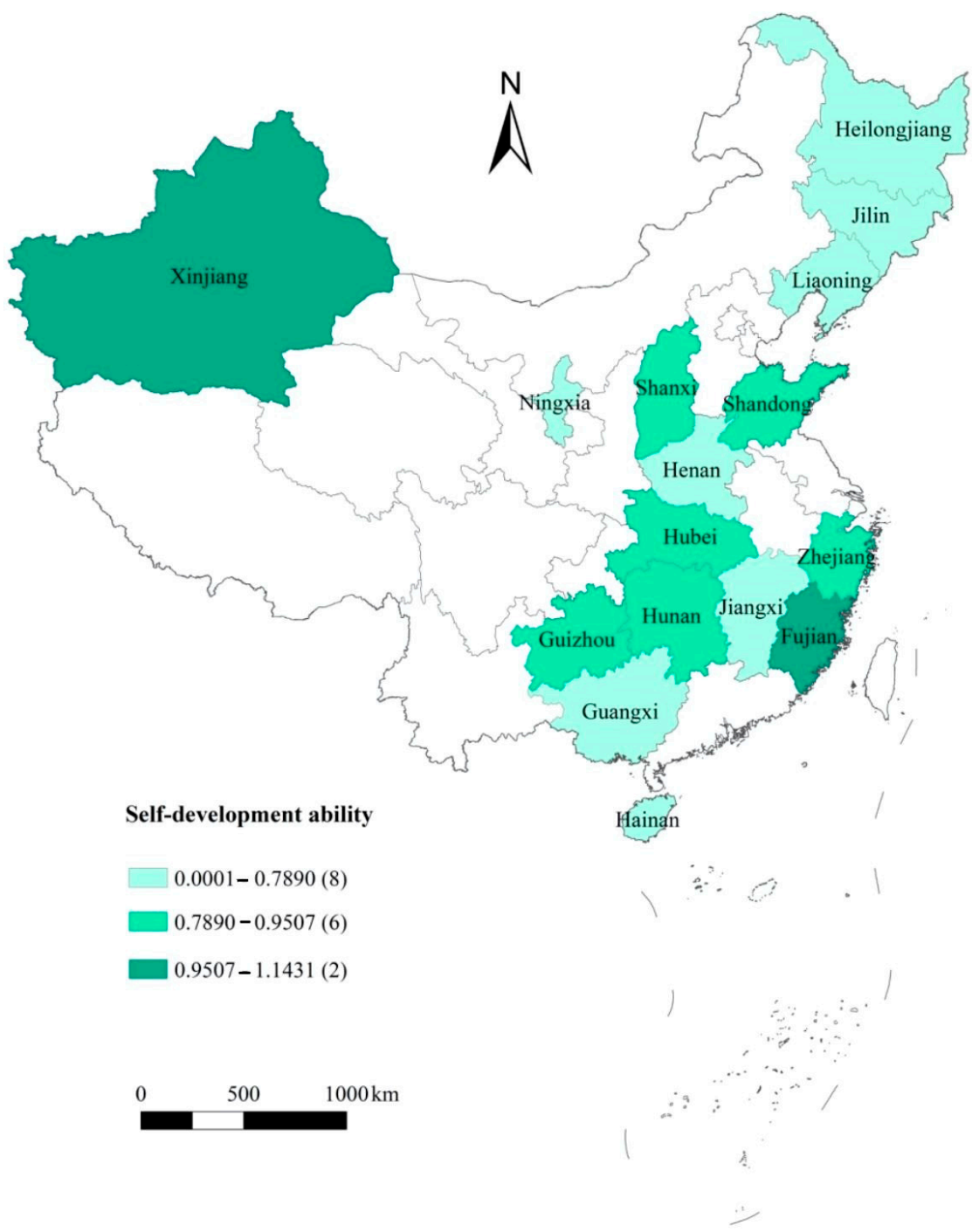

Figure 1. Spatial distribution of self-development abilities of SOFFs in 16 provinces (note: white indicates the non-sampled provinces).

Guangxi, Henan, Hainan, Liaoning, Heilongjiang, Jiangxi, Ningxia, and Jilin (eight provinces) are in the low-level area, with projection values of $0.7889,0.7860,0.7832,0.7732$, $0.7440,0.7198,0.6988$, and 0.5951 , respectively. There are two main reasons for the low self-development ability in Heilongjiang, Jilin, and Liaoning. The first is the climate problem that low temperatures all year round seriously affects their resource protection and economic development, including vegetation growth, economic forest cultivation, and the management of other industrial projects. The second is the management system problem that some social functions undertaken by SOFFs, such as schools and hospitals, cause management disorder. The main reason for the low ability of Ningxia and Henan is that these two places are not the key areas of forestry development and their forestry development is not valued there. Forestry development is important in Guangxi, Jiangxi, and Hainan, but the construction of SOFFs is in a weak position due to the restriction of the low level of local economic development, resulting in low self-development ability. 
There are clearly more provinces in the low- than in the high-level area; on the whole, the self-development ability of SOFFs remains weak. Although the SOFFs have benefitted from poverty alleviation efforts for 20 years and made reforms, their development mode has not been completely transformed. Therefore, their construction still assumes a weak position in social and economic development in China, including in terms of talent reserves, facilities, and scientific and technological support.

\subsubsection{Self-Development Abilities of SOFFs with Different Subordination Relationships}

The management subordination relationships of SOFFs in China are divided into three categories: provincial, municipal, and county. Among the samples, the number of county forest farms was the largest (1089) and the provincial number was the smallest (45) (Table 5). The categories of SOFFs rank in the following order in terms of their self-development abilities: municipal, provincial, and county; their projected values are 1.0168, 0.9462, and 0.7549 , respectively. The variance test results show a significant difference in the mean values among the three membership relationships; that is, the membership relationship has a significant influence on the self-development ability of the SOFF. This is because the subordinate relationship determines the management level of the SOFF, which affects the welfare of the employees, financial fund allocation, forest management planning, and political rights of forest farms. Compared with county forest farms, municipal and provincial forest farms have higher management levels and greater ability in resource acquisition.

Table 5. Self-development abilities of SOFFs with different subordination relationships.

\begin{tabular}{cccc}
\hline Subordination Relationship & Number & Projection Value & Variance Test \\
\hline Provincial Management & 45 & 0.946 & $\mathrm{~F}=70.32$ \\
Municipal management & 171 & 1.017 & $p=0.000$ \\
County Management & 1089 & 0.755 & \\
\hline
\end{tabular}

\subsection{Obstacle Degree Regarding Self-Development Abilities of SOFFs}

We used the obstacle degree model to determine the extents of obstacles for seven sub-dimensions that affect the self-development abilities of SOFFs.

\subsubsection{Obstacle Degrees in Each Province}

Table 6 shows that the factors posing obstacles for the self-development abilities of the SOFFs in Fujian, Xinjiang, Guizhou, Shandong, Zhejiang, Hunan, Hubei, Guangxi, Henan, Hainan, Liaoning, Heilongjiang, Jiangxi, and Jilin (14 provinces) are Social services (B7), People's livelihood security (B6), Management ability (B4), Forest resources (B1), Hardware construction (B2), Profitability (B5), and Innovation ability (B3), in order of influence from highest to lowest. However, the obstacle ranking in Shanxi Province and Ningxia is Social services (B7), Forest resources (B1), People's livelihood security (B6), Management ability (B4), Hardware construction (B2), and Profitability (B5). This means that improving social service ability is the primary issue in 16 provinces, while improving People's livelihood security is the secondary issue in the first 14 provinces, and improving forest resources is the secondary issue in the last two provinces.

In terms of the obstacle factors, the summed degrees of the first four obstacle factors are more than $85 \%$, indicating that B7, B6, B4, and B1 are the main factors inhibiting the abilities of SOFFs for self-development, while B2, B5, and B3 are not currently important. This is because on the one hand, the SOFF reform has solved the survival problem. SOFFs can maintain their own development, and hardware construction has been relatively perfect where there is no big problem. On the other hand, at present, SOFFs are in the stage of pursuing steady rise, and there is still a long way to go before the higher level development. Therefore, profitability and innovation ability are not the abilities that forestry farms urgently need to consider at present. 
Table 6. Degrees of obstacles regarding self-development abilities of SOFFs in each province.

\begin{tabular}{|c|c|c|c|c|c|c|c|c|}
\hline \multirow{2}{*}{ Province } & \multirow{2}{*}{ Ability Ranking } & \multicolumn{7}{|c|}{ Obstacle Factor (from Large to Small) } \\
\hline & & 1 & 2 & 3 & 4 & 5 & 6 & 7 \\
\hline Fujian & 1 & B7 $(32 \%)$ & B6 $(27 \%)$ & B4 $(19 \%)$ & B1 $(12 \%)$ & B2 $(8 \%)$ & B5 (2\%) & B3 $(1 \%)$ \\
\hline Xinjiang & 2 & B7 $(31 \%)$ & B6 $(22 \%)$ & B4 $(18 \%)$ & B1 (17\%) & B2 $(8 \%)$ & B5 $(2 \%)$ & B3 $(1 \%)$ \\
\hline Guizhou & 3 & B7 $(37 \%)$ & B6 $(21 \%)$ & B4 $(18 \%)$ & B1 $(13 \%)$ & B2 $(8 \%)$ & B5 $(2 \%)$ & B3 $(1 \%)$ \\
\hline Shandong & 4 & B7 (32\%) & B6 (24\%) & B4 (17\%) & B1 (16\%) & B2 $(9 \%)$ & B5 $(2 \%)$ & B3 $(1 \%)$ \\
\hline Zhejiang & 5 & B7 $(35 \%)$ & B6 (24\%) & B4 $(16 \%)$ & B1 $(14 \%)$ & B2 (8\%) & B5 (2\%) & B3 $(1 \%)$ \\
\hline Shanxi & 6 & B7 $(40 \%)$ & B1 (18\%) & B6 (17\%) & B4 (16\%) & B2 $(6 \%)$ & B5 (2\%) & B3 (1\%) \\
\hline Hunan & 7 & B7 (39\%) & B6 $(25 \%)$ & B4 (16\%) & B1 (11\%) & B2 (8\%) & B5 (1\%) & B3 (1\%) \\
\hline Hubei & 8 & B7 $(39 \%)$ & B6 $(23 \%)$ & B4 $(15 \%)$ & B1 (13\%) & B2 (8\%) & B5 (1\%) & B3 (1\%) \\
\hline Guangxi & 9 & B7 $(45 \%)$ & B6 $(22 \%)$ & B4 $(14 \%)$ & B1 $(10 \%)$ & B2 (7\%) & B5 (1\%) & B3 (1\%) \\
\hline Henan & 10 & B7 $(36 \%)$ & B6 $(25 \%)$ & B4 (16\%) & B1 (14\%) & B2 (7\%) & B5 (1\%) & B3 (1\%) \\
\hline Hainan & 11 & B7 $(46 \%)$ & B6 (21\%) & B4 (15\%) & B1 (11\%) & B2 (5\%) & B5 (1\%) & B3 (1\%) \\
\hline Liaoning & 12 & B7 $(44 \%)$ & B6 $(23 \%)$ & B4 $(14 \%)$ & B1 $(11 \%)$ & B2 (6\%) & B5 (1\%) & B3 (1\%) \\
\hline Heilongjiang & 13 & B7 (42\%) & B6 (22\%) & B4 (14\%) & B1 (13\%) & B2 $(6 \%)$ & B5 (1\%) & B3 (1\%) \\
\hline Jiangxi & 14 & B7 $(43 \%)$ & B6 $(23 \%)$ & B4 (15\%) & B1 $(10 \%)$ & B2 (7\%) & B5 (1\%) & B3 (1\%) \\
\hline Ningxia & 15 & B7 $(50 \%)$ & B1 (16\%) & B6 (14\%) & B4 (13\%) & B2 (5\%) & B5 (1\%) & B3 (0\%) \\
\hline Jilin & 16 & B7 $(44 \%)$ & B6 $(26 \%)$ & B4 $(13 \%)$ & B1 $(10 \%)$ & B2 (5\%) & B5 (1\%) & B3 $(1 \%)$ \\
\hline
\end{tabular}

\subsubsection{Obstacle Degrees at Different Development Levels}

We used the natural breakpoint classification method to subdivide the projection values for the self-development abilities of SOFFs into six groups from large to small, as shown in Table 7. For the first group with the largest projection value, the order of obstacle degrees is B6, B4, B7, B1, B2, B5, and B3, and for the other five groups, the order is B7, B6, B4, B1, B2, B5, and B3. This shows that B6 has the largest influence on SOFFs with high self-development abilities, while B7 has such an influence for those with low self-development abilities. This is because SOFF with high self-development abilities has better development conditions, need to consider seeking higher welfare treatment for the worker, and SOFF with low self-development abilities need to consider providing more social service construction to enhance the development conditions.

Table 7. Degrees of obstacles regarding self-development abilities of SOFFs at different development levels.

\begin{tabular}{|c|c|c|c|c|c|c|c|c|}
\hline \multirow{2}{*}{ Group } & \multirow{2}{*}{ Number } & \multicolumn{7}{|c|}{ Obstacle Factor (from Large to Small) } \\
\hline & & 1 & 2 & 3 & 4 & 5 & 6 & 7 \\
\hline $\begin{array}{c}\text { Group } 1 \\
(1.1936-1.5851)\end{array}$ & 154 & B6 (27\%) & B4 $(23 \%)$ & B7 $(21 \%)$ & B1 $(16 \%)$ & B2 $(10 \%)$ & B5 (2\%) & B3 (1\%) \\
\hline $\begin{array}{c}\text { Group } 2 \\
(0.9735-1.1936)\end{array}$ & 232 & B7 $(30 \%)$ & B6 $(24 \%)$ & B4 $(19 \%)$ & B1 $(16 \%)$ & B2 $(8 \%)$ & B5 (2\%) & B3 $(1 \%)$ \\
\hline $\begin{array}{c}\text { Group } 3 \\
(0.7880-0.9735)\end{array}$ & 119 & B7 $(47 \%)$ & B6 $(21 \%)$ & B4 $(14 \%)$ & B1 $(10 \%)$ & B2 $(6 \%)$ & B5 (1\%) & B3 (1\%) \\
\hline $\begin{array}{c}\text { Group } 4 \\
(0.6743-0.7880)\end{array}$ & 446 & B7 (50\%) & B6 (19\%) & B4 $(13 \%)$ & B1 $(11 \%)$ & B2 $(5 \%)$ & B5 $(1 \%)$ & B3 (1\%) \\
\hline $\begin{array}{c}\text { Group } 5 \\
(0.4647-0.6743)\end{array}$ & 154 & B7 $(46 \%)$ & B6 $(19 \%)$ & B4 $(13 \%)$ & B1 $(12 \%)$ & B2 $(8 \%)$ & B5 (1\%) & B3 (1\%) \\
\hline $\begin{array}{c}\text { Group } 6 \\
(0-0.4647)\end{array}$ & 200 & B7 (39\%) & B6 (35\%) & B4 (10\%) & B1 (9\%) & B2 (6\%) & B5 (1\%) & B3 (1\%) \\
\hline
\end{tabular}

The analysis of the obstacle factors showed the same result: the sum of the degrees of the first four obstacle factors is more than $85 \%$, showing them to be the main factors, while the last three play a small role. This means that self-development ability has little influence on the effect of obstacle factors. 


\subsubsection{Obstacle Degrees with Different Subordination Relationships}

Although there are obvious differences in the self-development abilities of SOFFs with the three subordination relationships, the obstacle factors that restrict development are the same, and the obstacle degree order is B7, B6, B4, B1, B2, B5, and B3, as shown in Table 8. The sum of the degrees of the first four obstacle factors is more than $90 \%$, implying that they are the main factors, while the last three play a small role. This result is similar to that above. This means that subordination relationship does not affect the effect of the obstacle factor.

Table 8. Degrees of obstacles regarding self-development abilities of SOFFs at different development levels.

\begin{tabular}{cccccccc}
\hline \multirow{2}{*}{ Subordination Relationship } & \multicolumn{7}{c}{ Obstacle Factor (from Large to Small) } \\
\cline { 2 - 7 } & $\mathbf{1}$ & $\mathbf{2}$ & $\mathbf{3}$ & $\mathbf{4}$ & $\mathbf{5}$ & $\mathbf{6}$ & $\mathbf{7}$ \\
\hline Provincial management & B7 $(35 \%)$ & B6 (25\%) & B4 (18\%) & B1 (13\%) & B2 (7\%) & B5 (2\%) & B3 $(1 \%)$ \\
Municipal management & B7 (40\%) & B6 (23\%) & B4 (16\%) & B1 (12\%) & B2 (7\%) & B5 (1\%) & B3 $(1 \%)$ \\
County management & B7 (42\%) & B6 (23\%) & B4 (15\%) & B1 (12\%) & B2 (7\%) & B5 (1\%) & B3 (1\%) \\
\hline
\end{tabular}

\section{Discussion}

\subsection{Relationship between Self-Development Ability of SOFFs and Positive Externalities of Forestry Production}

Although the existence problem of SOFFs has been solved, its self-development ability is still weak. This result is similar to those reported by $\mathrm{Xu}$ et al. [31], Zheng et al. [32]. The weak self-development ability of SOFFs is closely related to the positive externality of forestry production. The possible reasons are as follows: (1) The positive externality of forestry production makes forestry investment income less than social income, which not only leads to low resource allocation efficiency of SOFFs, but also makes it difficult for SOFFs to attract social capital investment; (2) In order to solve the positive externalities of forestry, the government designated SOFFs as public institutions ( $95 \%$ of which are public welfare institutions). Although this has effectively avoided the loss and destruction of forest resources, but employees' wages were allocated by local finance, which also reduced their enthusiasm for forestry. (3) The positive externality of forestry is mainly reflected in the public benefits generated by forestry, i.e., ecological performance and social performance, which cannot be compensated. This determines that the SOFF must undertake the social responsibility of maintaining the ecological environment, that is, the ecological performance and social performance of the SOFF are more important than the economic benefits. The positive externality of forestry is an inherent attribute and inevitable, but the improvement of the self-development ability of SOFFs cannot be ignored. Market mechanism should be properly introduced into the management of SOFFs to improve the efficiency of resource allocation and the ability of self-development through government purchasing behavior.

\subsection{Government Support Has Limited Impact on the Development of SOFFs}

The development of SOFFs has obtained a lot of policy support from the government, but the self-development ability is still not high. The possible reasons are as follows: (1) The policy support from the government only provides external impetus for the development of SOFFs. However, to truly revitalize and develop SOFFs, they need to fundamentally rely on internal impetus, such as high-end talents and advanced management concepts. (2) The management of SOFFs is directly or indirectly affected by government intervention. The development of SOFFs that completely depends on the unified planning and management of local governments [33], is greatly influenced by the planned economy and has little enthusiasm for exploring new development paths. (3) There are 4588 SOFFs all over China, a huge number, but the government has not come up with an effective classified management strategy. Most scholars divide SOFFs into three types such as public welfare-oriented, commerce-oriented, and mixed [34], but this classification strategy has very low operability in practice and has not been widely used. The key to enhance the self-development ability 
of SOFFs lies in tapping their own potential, revitalizing forest resources, and realizing diversified management, rather than relying on government support.

\subsection{Sample Limitations of the Research}

The existing evaluation methods seldom consider the interactions among the dimensions composed of indicators. In this study we combined SEM and PPM to consider such interactions, in order to increase the scientificity. However, due to the limitations of the data quality and sources, the sample omitted 34 provinces (cities and autonomous regions) in China, limiting the applicability of the conclusions. We also adopted cross-sectional rather than panel data, precluding the analysis of SOFF development trends in recent years. These two aspects warrant further study in future research.

\section{Conclusions}

Improving the ability for self-development is the main development direction for a SOFF after reform and rising from poverty. In this study we constructed a system to evaluate the self-development abilities of SOFFs according to their characteristics and selfdevelopment ability theory, and then evaluated it by combining SEM and PPM. We finally analyzed obstacle factors in 16 provinces, at different development levels and with different subordinate relations with a degree model. The following conclusions can be drawn: (1) The self-development abilities of SOFFs remain weak, and there are significantly more provinces in low- than high-level areas. Reforms in 2015 and the poverty alleviation work over the past 20 years have solved systemic and mechanistic problems. The construction funds have ensured survival, but most SOFFs are still in a weak position regarding development. We thus need to explore a new development model for the future. (2) The subordination relationship has a significant influence on the self-development abilities of SOFFs, which are the strongest among municipal SOFFs, followed by provincial and county SOFFs. The county SOFFs, possessing the lowest abilities for self-development, are the most abundant by proportion in China, so future policies concerning the development of forest farms should focus more on such farms. (3) In 16 provinces, at different development levels, and with three subordinate relationships, social services, people's livelihood security, management ability, and forest resources are the main factors limiting the self-development abilities of SOFFs, while hardware construction, profitability, and innovation ability are not important. For SOFFs with high self-development abilities, people's livelihood security is the main factor restricting further improvement, while for those with low self-development abilities, it is social services. As public welfare institutions, SOFFs require good social service abilities to meet their responsibilities; the ability for ensuring people's livelihood security is the basis for this, the management ability is the guarantee, and the ability for protecting forest resources is the foundation. The improvement of these four abilities is the top priority for SOFFs.

Based on the development trend of Chinese forestry and the results of self-development ability evaluation and obstacle degree analysis of SOFFs, the following four policy suggestions were put forward to improve the self-development ability of SOFFs. First, strengthening the state financial support and policy support is still an important support force for the maintenance of most SOFFs. Standardize the use of SOFFs' various funds, including the reform subsidy funds from the central finance and the reform costs from provincial finance. The eligible policies supporting agriculture and benefiting agriculture will be applied to SOFFs, and the policy support for basic public services of SOFFs will be strengthened to realize the equalization of basic public services with surrounding areas. Second, the management level of SOFFs should be improved. That is, county forest farms should be upgraded to provincial forest farms or municipal forest farms. On the one hand, the administrative status of SOFFs is improved and the right to obtain more development resources is increased. On the other hand, the hierarchical management system of SOFFs is reduced and the efficiency of policy implementation of SOFFs is accelerated. Third, we should accelerate the transformation of SOFFs, and draw lessons from foreign state-owned 
forest management, that is, maintain state-owned property right and introduce market mechanism in forestry management. Explore the sustainable management mode from "cutting down trees" to "looking at trees" to form a diversified management mechanism. SOFFs can purchase services from the society through government contracts and entrustments to realize the management and protection of public welfare forests and give play to the role of market mechanism. While protecting forest resources, social capital, and employees of SOFFs are encouraged to develop characteristic industries such as forest tourism, so as to effectively revitalize forest resources and increase the vitality of the development of forest farms. Fourth, strengthen the construction of talent team of SOFFs and improve the welfare level of employees. Most of the state-owned forestry farms are located in remote areas with poor production and living conditions, which greatly reduces the attraction of new talent. It is necessary to relax the conditions of professional and technical position evaluation and employment in SOFFs in difficult areas and strengthen the skill training of SOFF workers. Improving the production and living conditions of SOFFs and perfecting the social security mechanism of the workers are helpful to enhance the sense of gain and happiness of the workers.

Author Contributions: Data calculation and analysis, paper editing, J.B.; Data curation and funding acquisition, W.C.; supervision, P.T.; project administration, J.L. All authors have read and agreed to the published version of the manuscript.

Funding: This research was supported by the National Natural Science Foundation of China (Grant No: 71573018).

Institutional Review Board Statement: Not applicable.

Informed Consent Statement: Informed consent was obtained from all subjects involved in the study.

Data Availability Statement: Data would be available by contacting authors.

Acknowledgments: The authors are grateful for financial support from the National Natural Science Foundation of China (NSFC, project no. 71573018).

Conflicts of Interest: The authors declare no conflict of interest.

\section{References}

1. Liao, W.; Wang, X.; Liu, X. From survival to self-esteem: On the construction of public libraries' self-development capacity in Chinese less-developed areas. Libr. Trib. 2018, 38, 30-37.

2. Ni, X. Research on the Development Ability of Specialized Farmer Cooperatives. Ph.D. Thesis, Northwest Agriculture \& Forestry University, Xianyang, China, 2012.

3. Zeng, S.; Zhang, S.; Li, J.; Yang, L.; Xiao, C.; He, M. Evaluation of self-development ability of tobacco farmers' cooperative in Hunan Province. Acta Tab. Sin. 2018, 24, 100-105.

4. Luo, H.; Fu, J. Comprehensive evaluation system for modern agricultural demonstration garden: A case study of the Dianbu Carrot Garden in Qingdao. Res. Agric. Mod. 2017, 38, 1059-1066.

5. Fu, S. Quantitative analysis of self-development capacity and improving paths and ideas for new energy industries in the west. Reform Econ. Syst. 2015, 1, 188-193.

6. Li, X. Application of a combined multivariate statistical method in cultural industry evaluation. Stat. Decis. $2019,35,83-85$.

7. Shen, J.; Chen, Y. Research on network analysis method for development ability of big data industry in underdeveloped area. J. Commun. 2017, 38, 153-159.

8. Qin, L.; Hu, J.; Zhu, K.; Li, Y. Evaluation of the development capability of the sixth industry based on "Internet +" and collaborative innovation mode-A case study of Guangxi. Jiangsu Agric. Sci. 2019, 47, 321-326.

9. Wang, Z.; Zhang, Y. Research on the development capability evaluation system of small and micro enterprises in line with the new needs. Dong Yue Trib. 2017, 38, 186-192.

10. Wang, H.; Zhang, P. On comprehensive evaluation of SOEs self-development capability in XJPCC. J. Xinjiang Univ. 2014, 42, 15-19.

11. Feng, M.; Pi, W. A empirical study on the hierarchical dynamic competency about enterprise managers-Based on the DEMATEL analysis model. East China Econ. Manag. 2013, 27, 129-137.

12. Demerjian, P.; Lev, B.; McVay, S. Quantifying managerial ability: A new measure and validity tests. Manag. Sci. 2012, 58, 1229-1428. [CrossRef] 
13. Aghion, P.; Harris, C.; Howitt, P.; Vickers, J. Competition, imitation and growth with step-by-step innovation. Rev. Econ. Stud. 2001, 68, 467-469. [CrossRef]

14. Lin, Y.; Wang, Y.; Chiou, J.; Huang, H. CEO characteristics and internal control quality. Corp. Gov. Int. Rev. 2014, 22, 24-42. [CrossRef]

15. Yang, X.; Peng, C.; Yao, A. Management capability, internal control and corporate sustainability. Audit. Res. 2018, 1, 121-128.

16. Xia, B.; Hou, X. Internal control, social responsibility and sustainable development ability of enterprises. J. Xi'an Univ. Technol. 2018, 34, 246-252.

17. Francis, B.; Hasan, I.; Wu, Q. The compact of CFO gender on bank loan contracting. J. Audit. Financ. 2013, 28, 53-78.

18. Luo, P.; Weng, M.; Chen, Z.; Guan, C.; Du, S.; Hao, M. Study on comprehensive benefit evaluation of Huangfengqiao state-owned forest farm. For. Econ. 2016, 38, 79-83.

19. Xie, D.; Hu, M. Research on the classification index system design of the state-owned forest farms based on correlation analysis and principal component analysis. J. Cent. South Univ. For. Technol. 2016, 36, 141-146.

20. Miao, F.; Ye, Y. Study on sustainable management index system of state owned forest farm in sub-tropical are. Probl. For. Econ. 2016, 36, 558-564.

21. Wang, M.; Chen, W. Study on the development level of state-owned forest farms in county areas-A case study of Hebei province. Probl. For. Econ. 2017, 37, 35-40.

22. Xu, D.; Wang, L.; Liu, J. Assessing the social performance of state-owned forest farms in China: Integrating forest social values and corporate social responsibility approaches. Scand. J. For. Res. 2017, 32, 338-348. [CrossRef]

23. Sun, G. On the Construction of the Self-Development Capacity in Western China. Ph.D. Thesis, Southwest University of Finance and Economics, Chengdu, China, 2013.

24. Wang, W. A study on Capability of Resource Agglomeration and Relationship between That and Economic Growth in Western Regions. Master's Thesis, Guangxi Normal University, Nanning, China, 2015.

25. Zhang, Z. Measuring model and criterion of forestry ecological security by symbiotic coupling method. China Popul. Resour. Environ. 2014, 24, 90-99.

26. Shao, Z.; Wu, K. Chinese families carrying capacity: Construction of index system and its evaluation. South China Popul. 2018, 33 , 24-35.

27. Xu, L.; Zhang, F. The study of heterogeneity relationship of profitability and capital structure of real estate listed companiesBased on quantile regression for dynamic panel data. Shanghai Econ. Rev. 2015, 1, 119-127.

28. Li, J.; Qi, Q. Study on the performance evaluation system of listed cultural media companies. J. Southeast Univ. Philos. Soc. Sci. 2015, 17, 44-46.

29. Liu, J.; Chen, W.; Hu, M. Theoretical Analysis and Practical Research on Poverty Alleviation of State-Owned Forest Farms; Tsinghua University Press: Beijing, China, 2016.

30. Su, Q.; Yu, Y. Evaluation of sustainable development ability of enterprises based on accelerating genetic algorithm projection pursuit model. Oper. Res. Manag. Sci. 2018, 27, 130-139.

31. Liu, P. Improve infrastructure construction to break the bottleneck of the reform of state-owned forest farms in Xinjiang. For. Xinjiang 2016, 1, 10-12.

32. Zheng, J.; Feng, Y.; Dai, Y. Study on performance evaluation of Inner Mongolia state-owned forest farms based on three-stage DEA model. Probl. For. Econ. 2017, 37, 23-29.

33. Chen, R.; Chen, W.; Hu, M.; Huang, W. Measuring improvement of economic condition in state-owned forest farms' in China. Sustain. 2020, 12, 1593. [CrossRef]

34. Zhu, Y.; Wei, Y.; Cheng, J.; Tang, Z. Discussion on classification management oriented reform of state-owned forest farms. Beijing Linye Daxue Xuebao/J. Beijing For. Univ. 2001, 23, 61-66. 